MIDPI

sciforum

\title{
Evaluation of the operation parameters and the process quality of the obtaining of granulated panela in the parish of Tarqui, in the panela industry "El Valle"
}

\author{
Julia M. Escobar $1^{a}$, Víctor R. Cerda $2^{b}$, Andrea S. Tapuy $3^{c}$. \\ Universidad Estatal Amazónica, Departamento de Ciencias de la Tierra, Carrera de Ingeniería \\ Agroindustrial, Laboratorio de Química,Proyecto de Vinculación:, mescobar@uea.edu.ec, \\ vcerda@uea.edu.ec: atapy@uea.edu.ec.
}

\section{Graphical Abstract}

Insert grafical abstract figure here

\section{Abstract.}

Sugar cane (Saccharum officinarum L.) is a crop with a high worldwide demand due to being the main source of sucrose and the wide range of products obtained. The production of granulated panela in the province of Pastaza is currently part of the diverse products that are obtained through sugar cane, being of great agroindustrial interest. By means of a descriptive questionnaire applied to 13 panela fabricants of the parish of Tarqui, identified that only one had sanitary registration and has faced problems such as: price instability, insufficient demand, regular infrastructure, limited process conditions, a lack of knowledge of the quality and control. The following presentation carried out a diagnostic of the operational parameters $(\mathrm{pH}$, Brix, Temperature, Performance) of the process and the quality of the panela (\% moisture, $\%$ cinder y color) in the industry "El Valle" for the duration of three months and determined that in the reception, extraction, clarification and evaporation $(1,2,3,4)$, the $\mathrm{pH}$ values, brix and temperature are below the lower limit, while the performance of the trapiche is in an acceptable range, between 53-69\%. With respect to the quality parameters, the values are within what is established in the NTE INEN 2 332:2002 for granulated panela 
with the moisture content of $2.8 \%, \mathrm{pH}: 5.98$ and cinder $0.63 \%$.

\section{Introduction (optional)}

. In Ecuador, the panela productive chain is composed of public and private producers, by productive and commercial links. Demand of panela has incentivized both large and small producers to diversify and increase their production. (Carlosama, 2009) ASOCAP in the year 2000, revealed that in the province of Pastaza, the productivity of panela represents a very important part of the economy, which generates and work to families through the participation in the processes of cultivation, processing, transportation and commercialization (Guevara, 2011). Currently, according to the Autonomous Decentralized Government of the Province of Pastaza from the diagnostic of the ASOCAP, 2010, there are 212 granulating factories, and their sugar non-centrifugal fabricating activity is absorbed and processed in three central sugar non-centrifugal fabricants that work according to the production capacity of the canton (Tarqui, Fatima and Madre Tierra). (Palacios, 2012)

In the parish of Tarqui, the panela fabricants carry out the elaboration of panela based on artisanal techniques, where the facilities and infrastructure do not meet the sanitary conditions, because the constructions are made of wood, thatched roofs and dirt floors, which is not suitable in an industrial panela fabricant (Quezada, 2007).

The process of panela production in small industrial panela fabricants is done with between 1 and 2 pails, burners with different degrees of efficiency, mills powered by or moved with animals, in other cases with diesel engines or firewood as fuel and maintaining ancestral techniques. In the case of the main panela fabricants, panela production has undergone transformations in the juice extraction process, which has gone from using internal combustion engines to electric motors and to processing large areas of cane and reducing the consumption of wood. (Palacios, 2012)

Agro-ecological factors such as relief, soil, height, hours of light, winds and rainfall, storage conditions of the sugar cane, pre-cleaning and cleaning of juices, amount of added lime, clarification method, lime purity, type and dosage of the Flocculant, heating speed, energy efficiency of the process, temperature of the tap, method of beating and storage conditions are causes that influence the sensory and physical attributes of panela. (Hernández et al., 2004; Hernández, 2005; Solórzano et al., 2013).

In the parish of Tarqui there are 13 central panela fabricants dedicated to the artisanal production of panela in solid and granulated forms, for this reason it is necessary to evaluate the parameters of operations and quality of the product coming from the "El Valle" panela fabricant, if it corresponds to the standard Ecuadorian technical norm NTE INEN 2332 (2002) that defines granulated panela as "the product obtained by concentrating sugarcane juices, until a thick syrup is obtained, allowing the syrup to solidify and granulate by shaking" processes that they must be controlled in the artisanal sector and complemented with attributes of color, hygiene and presentation for the commercialization of products towards the consumer.

\section{Materials and Methods (optional)}

. The present study is the result of a linking project "Strengthening of knowledge and skills in the control of the operational and quality parameters of the process of obtaining panela from the parish of Tarqui, in the panela fabrication industry "El Valle". With the objective of evaluating the operational parameters (Performance, pH, Brix, Temperature) during the Reception, Extraction, Clarification, Evaporation 
process and followed the parameters in the factory using record cards to collect ten data for each stage of the process and temperature measurement equipment were used (Proster Digital Laser Infrared thermometer $-50-380^{\circ} \mathrm{C}$ ), pHmeter (APERA PC60), Brix (Boeco Germany).

The evaluation of the quality (\% moisture, ash and color) of the granulated panela was carried out using a probabilistic sampling, which was analyzed in the Chemistry Laboratory of the State University of Amazonia, based on the Ecuadorian Technical Standard NTE INEN 2331 , 2332 (2002). The data obtained was tabulated using the descriptive statistics and average values of the parameters evaluated.

\section{Mill performance}

The performance of the sugar mill was taken in the extraction stage, using the CAMRY scale; maximum capacity of $50 \mathrm{~kg} / 110 \mathrm{lb}$. Six rods taken at random from the production lot were weighed and the test was done three times using the following formula $\% \mathrm{Ep}=(\mathrm{Pj} / \mathrm{Pc}) 100$ where $\mathrm{Ep}=$ Extraction weight $; \mathrm{Pj}=$ Juice weight; $\mathrm{Pc}=$ Sugar cane weight.

\section{pH determination}

The measuring of $\mathrm{pH}$ in the reception stage was direct, the sugar cane juice was taken from the base part, and for the measurement of the $\mathrm{pH}$ from the taken samples of the evaporation pails that were previously diluted with distilled water with the relation of 1:1 in ambient temperature, using a calibrated pHmeter of brand APERA PC60.

\section{Determination of soluble solids}

The determination of the soluble solids in the reception and extraction stage used refractometer Boeco Germany model BCBI9177, with a Brix scale range: 0-32\% with a prevision of $\pm 0.2 \%$; Samples with an elevated concentration of solids in the evaporation stage, were diluted in a proportion of 1:1 of panela - water, distilled and and a refractometer Atago HSR-500 was used with a scale range of $0.0 \%-90.0$ $\%$ with a precision of $\pm 0.2 \%$.

\section{Determination of moisture}

The determinations were twice made using the method proposed in the Standard INEN 2331, 2332 (2002). $5 \mathrm{~g}$ of raw sugar or panela was placed in a nickel capsule, weighed on the Larko analytical balance with a degree of appreciation of $\pm 0.001 \mathrm{~g}$; they were placed in the oven at $65^{\circ} \mathrm{C}$ for 2 hours, once the time elapsed they were removed from the stove, allowed to cool and put in a desiccator for 30 minutes, again weighed in the analytical balance and the percentage of moisture was calculated by the formula: $\% \mathrm{H}=(\mathrm{m} 1-\mathrm{m} 2) / \mathrm{m} * 100$. Where: $\mathrm{m}=$ mass of the sample, $\mathrm{m} 1$ : mass of the capsule, with the sample, before heating and $\mathrm{m} 2$ : mass of the capsule, with the sample, after heating.

\section{Determination of ashes}

The analysis was twice carried out using the total ash method (calcination) (Kirk et al, 1996). 3 to $5 \mathrm{~g}$ of sample were weighed in the crucible (the sample must not exceed half of the crucible) previously weighed, the sample was calcined, first with a lighter in the bell until no fumes were released and later introduced to the muffle for 2 hours ensuring that the temperature did not exceed $550^{\circ} \mathrm{C}$. After cooled in a desiccator, weighed up to constant weight and calculated with the formula :\% $\mathrm{C}=\mathrm{m} 2 / \mathrm{m} 1 * 100$ Where: $\mathrm{m} 1$ : mass of the sample before calcination and $\mathrm{m} 2$ : mass of the capsule, with the sample, after calcination .

\section{Results and Discussion (optional)}




\section{Description of the process of obtaining panela.}

The company "El Valle" has a space covered in zinc for the reception of the sugar cane, which then passes to a mill where the juice is extracted and in turn by a pre-cleaner it is sent by PVC hoses to the tank clarifier Once clarified the juice goes to the first pan where the evaporation process begins, once the boiling of the fluid begins with the help of steel shovels the fluid is distributed to the second, third and fourth pail to facilitate the concentration of soluble solids taking advantage of the available heat of the furnace, this in turn is fed with sugar cane bagasse and wood for heat generation. Finally the process culminates with the shaving and molding of the mollases using steel blades to cool it in the case that it is a solid block or beat until it crystallizes if it is granulated, closing the cycle with the packaging in high density plastic covers covered by pouches and storage at room temperature until distribution. According to Mosquera 2007, the initial control and throughout the process of obtaining panela affects the quality of the product and constant factors such as the degree of maturity, variety of raw material generate large effects in the final product

Figure 1. Process of elaboraton of panela, "Panela fabricant el Valle"

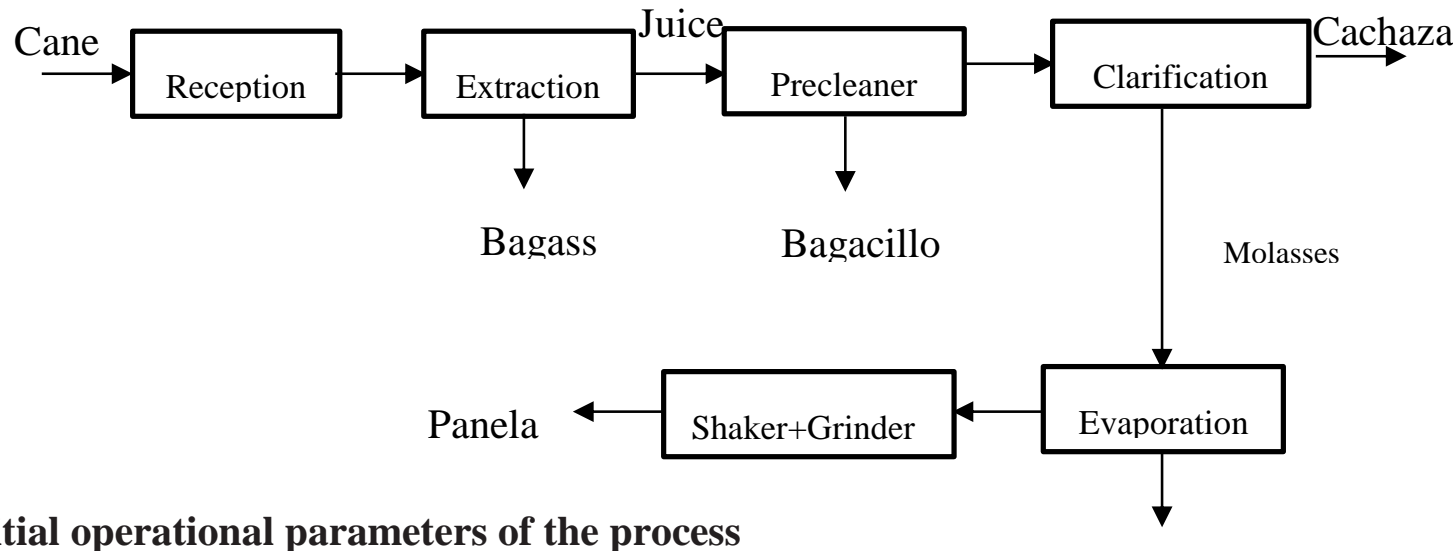

Initial operational parameters of the process

Chart 1 presents the initial mean values taken at the reception where Ylieprercentage of juice extracted from sugarcane indicates that the yield is regular at $63.1 \%$ and a highly significant standard deviation of 5.3. According to Quezada, 2012 for a good extraction the mills panela workers must calibrate the speed of rotation of the clubs and spaces between them, it is recommended that the speed of rotation is from 6 to $15 \mathrm{rpm}$. With speeds higher than those indicated, more cane is milled per hour but the extraction capacity decreases and good extractions are estimated between 50 to $65 \%$. The values of ${ }^{\circ}$ Brix are outside the optimum range with average of $16.3^{\circ}$ Brix and according to Quezada, 2007 the ranges can be due to the type of crop, state of maturity, number of cuts, climatic conditions, freshness, not storing it for more than 24 hours after cutting and recommend optimal values of 22 and $24^{\circ}$ Brix. The $\mathrm{pH}$ values are related to the state of maturity and for the initial stage of the process the optimum range is $4.5-5$, the data obtained indicates that the $\mathrm{pH}$ is within the recommended to $95 \%$ confidence.

Table 1. Average values of operational parameters at the beginning of the process.

\begin{tabular}{|c|c|c|c|c|c|c|}
\hline \multirow{2}{*}{$\begin{array}{c}\text { START OF } \\
\text { PROCESS }\end{array}$} & \multicolumn{4}{|c|}{$\begin{array}{c}\text { Mill performance } \\
(\%)\end{array}$} & Soluble Solids $\left({ }^{\circ}\right.$ Brix) & \multicolumn{2}{|c|}{ pH } \\
\cline { 2 - 7 } & $\begin{array}{c}\text { Average } \\
\text { value }\end{array}$ & $\begin{array}{c}\text { Standard } \\
\text { Deviation }\end{array}$ & $\begin{array}{c}\text { Average } \\
\text { Value }\end{array}$ & $\begin{array}{c}\text { Standard } \\
\text { devation }\end{array}$ & $\begin{array}{c}\text { Average } \\
\text { value }\end{array}$ & $\begin{array}{c}\text { Standard } \\
\text { Deviation }\end{array}$ \\
\hline Reception & 63.1 & 5.3 & 16.3 & 1.5 & 5.4 & 0.4 \\
\hline
\end{tabular}




\section{Operational parameters during the process}

As a result of the measurement of soluble solids and temperature, Chart 2 shows the increase of ${ }^{\circ}$ Brix and ${ }^{\circ} \mathrm{C}$ with highly significant standard deviations in a $95 \%$ confidence interval, this variation is due to the fact that the system used is open in the panel "El Valle", making both evaporated water and the energy generated not used efficiently and affecting the different qualities of the granulated panela obtained. In this stage the juice boils and loses water by evaporation, thus it goes from one evaporator to another pushed by a pressure difference until reaching between $92-96^{\circ}$ Brix, having to take care of the temperature since sucrose is a product that when reaching certain conditions can present chemical decomposition and the $\mathrm{pH}$ values should range between 6 to 7 to avoid losses of sucrose. (Prada Forero, García Bernal, \& Chaves Guerrero, 2015)

Table 2. Average values for operational parameters during the process.

\begin{tabular}{|c|c|c|c|c|}
\hline \multirow{2}{*}{ PROCESS } & \multicolumn{4}{|c|}{ PARÁMETROS OPERACIONALES } \\
\cline { 2 - 5 } & Soluble Solids $\left({ }^{\circ}\right.$ Brix) & Temperatura $\left({ }^{\circ} \mathbf{C}\right)$ \\
\cline { 2 - 5 } & $\begin{array}{c}\text { Average } \\
\text { value }\end{array}$ & $\begin{array}{c}\text { Standard } \\
\text { deviation }\end{array}$ & $\begin{array}{c}\text { Average } \\
\text { value }\end{array}$ & $\begin{array}{c}\text { Standard } \\
\text { deviation }\end{array}$ \\
\hline Evaporator 1 & 55.7516129 & 4.03 & 87.0041667 & 8.7 \\
\hline Evaporator 2 & 68.1419355 & 10.9 & 89.05 & 6.2 \\
\hline Evaporator 3 & 84.295122 & 5.2 & 93.4441176 & 9.6 \\
\hline Evaporator 4 & $>90$ & ----- & 109.43 & 35.5 \\
\hline
\end{tabular}

\section{Quality parameters of granulated panela}

The average value of $\mathrm{pH}$ registered (Chart 3) shows that it complies with the requirements of the Ecuadorian Technical Standard INEN 2332: 2002 where the minimum pH value is 5.9 and are similar to those presented by Quezada (2007) who indicates that to have panela of sufficient quality with natural color the $\mathrm{pH}$ should be close to 5.7. The average moisture of the samples of granulated panela analyzed was $2.36 \%$ (Chart 3 ) compared to the regulation that stipulates a maximum value of moisture is $3 \%$ with a standard deviation of 0.57 to $95 \%$ confidence, which is to say that it meets this criteria. The quality of panela depends on the concentration of direct reducing sugars (ARD), influencing the consistency of the final product, with the molding stage being a very important step (Andrade, 2008), including that the high temperatures during the process trigger the reaction of Maillard, responsible for the characteristic color and smell (Fernández, 2003). The determined ash content (Chart 3) presents an average value of $0.59 \%$ that according to the nutritional composition presented by Mascietti 2014, the ash content represents $0.5 \%$ of minerals present in panela such as Calcium, Potassium, Iron, among others, which are essential for the current diet and have an impact on factors such as the variety of the cane, the type of soil, age of the crop, climatic characteristics and production process (Obando, 2010)

Table 3. Average values of the quality parameters of quality of granulated panela.

\begin{tabular}{|c|c|c|c|c|c|c|}
\hline \multirow{2}{*}{$\begin{array}{c}\text { GRANULATED } \\
\text { PANELA }\end{array}$} & \multicolumn{4}{|c|}{ QUALITY PARAMETERS } \\
\cline { 2 - 7 } & $\begin{array}{c}\text { Average } \\
\text { Value }\end{array}$ & $\begin{array}{c}\text { Standard } \\
\text { Deviation }\end{array}$ & $\begin{array}{c}\text { Average } \\
\text { Value }\end{array}$ & $\begin{array}{c}\text { Standard } \\
\text { Deviation }\end{array}$ & $\begin{array}{c}\text { Average } \\
\text { Value }\end{array}$ & $\begin{array}{c}\text { Standard } \\
\text { Deviation }\end{array}$ \\
\hline Reception & 2.4 & 0.6 & 5.98 & 0.1 & 0.59 & 0.4 \\
\hline
\end{tabular}

\section{Conclusions (optional)}


In the province of Pastaza, the panela industry is going through obsolete infrastructure problems, price instability in the market, deficiencies in the control of the process and the quality of panela. This can consequently change through the application of state policies that support the farmer for the integral management of sugar cane cultivation, control systems that guarantee quality products and the training of operators that are part of an economically active sector. The values identified in the panela fabricant "El Valle" show that there are no procedures for the control of operational parameters in all stages of the process reception, extraction, clarification, evaporation, shaking and molding that is to say that it is carried out empirically based on the experience of the operator. In terms of productivity and efficiency, the current system presents economic losses for the small product, added to this is the waste of heat energy generated by the combustion of sugar cane bagasse, affecting characteristics such as the color variability and soluble solids content of panela. However, the moisture and $\mathrm{pH}$ required in the Ecuadorian Technical Standard INEN 2332: 2002 for the quality of granulated panela the product complies with the specifications, the percentage of total minerals registered together with the organoleptic properties offered by the product of the parish of Tarqui is very appreciated because the crops are grown in a geographical area that provides these characteristics.

\section{References (mandatory)}

Andrade M. 2008. Evaluación de la funcionalidad de panelas artesanales como antioxidante y fuente de minerales. Universidad Simón Bolivar. Sartenejes, Venezuela. pp: 31-46.

Cabrera, C. G., \& Cabrera, H. F. G. (2001). Clarificación del guarapo de caña de azúcar en la producción de panela. Revista Facultad Nacional de Agronomía, 54(1 y 2), 1211-1239.

FAO. (2004). Registro Sanitario Importación, Desalmacenaje y Vigilancia de Alimentos, Decreto.

Fernández L. N. 2003. Estudio para la implementación de una planta de producción de panela (tesis de maestría). Universidad de San Carlos de Guatemala. Facultad de Ingeniería. Escuela de mecánica Industrial. Guatemala. 119 p.

Mosquera S. A., Carrera E. J., Villada H. S. 2007. Variables que afectan la calidad de la panela procesada en el departamento del Cauca. Facultad de Ciencias Agropecuarias. Cauca Colombia. 5: 17-27.

Prada Forero, L. E., García Bernal, H. R., \& Chaves Guerrero, A. (2015). Effect of the variables of evaporation: pressure and heat flux in the quality of panela. Corpoica Ciencia y Tecnología Agropecuaria, 16(1), 723.

Solís J., Pérez F., Orozco I., Flores J., Ramírez E., Hernández A., Aguilar B. 2006. Descripción de un proceso tecnificado para la elaboración de piloncillo a partir de caña de azúcar. e-Gnosis

4: $1-8$.

Solórzano, Carmen; Montilva, Leonarda (2016), Evaluación de parámetros de calidad en panelas de los municipios Sucre, Junín, Ayacucho y Cárdenas del estado Táchira, Venezuela. Universidad Nacional Experimental del Táchira, San Cristóbal, estado Táchira, Venezuela

Quezada Moreno, W. F. (2012). Guía técnica de agroindustria panelera. Ibarra, Ecuador. 